\title{
Aplikasi Lean Six-Sigma untuk Mengurangi Pemborosan di Bagian Packaging Semen
}

\section{Lean Six-Sigma Application to Reduce Waste in Cement Packaging}

\author{
Reni Dwi Astuti*, Lathifurahman \\ Jurusan Teknik Industri, Fakultas Teknologi Industri, Universitas Ahmad Dahlan Yogyakarta \\ Kampus 4 UAD, Jl. Ring Road Selatan, Tamanan, Bantul, D.I.Y. \\ Email: reni_dwiastuti@ie.uad.ac.id
}

\begin{abstract}
ABSTRAK
Observasi pada penelitian ini menunjukan adanya pemborosan di bagian pengepakan semen dan adanya produk cacat kemasan. sehingga banyak semen tercecer mengakibatkan pengulangan proses pengepakan terjadi. Penelitian ini dilakukan untuk mengidentifikasi pemborosan pada proses pengepakan menggunakan pendekatan lean manufacturing dengan value stream mapping. untuk tingkat kualitas, penelitian ini menggunakan dengan metode sixsigma. Penyebab kecacatan produk dianalisis dengan fish-bone diagram. lebih lanjut, Failure Mode and Effect Analysis (FMEA) digunakan untuk merancang ususlan perbaikan. hasil penelitian ini menunjukan adanya Pemborosan pada transportation, motion, waiting, over processing, dan defect. Usulan perbaikan dilakukan dengan penggabungan stasiun penimbangan dan stasiun pemeriksaan, sehingga memberikan estimasi peningkatan effisiensi dari $39.1 \%$ menjadi $46.69 \%$.
\end{abstract}

Kata Kunci: semen, six sigma, lean manufacturing, value stream mapping, failure mode and effect analysis

\begin{abstract}
Observations in this study indicate that there is waste in the cement packing and packaging defects. Thus, a lot of cement is scattered resulting in a repetition of the packing process. This research was conducted to identify waste in the packaging process using lean manufacturing approaches with value stream mapping. To the level of quality, this study uses the six-sigma method. The causes of product defects were analysed with a fish-bone diagram. Furthermore, Failure Mode and Effect Analysis (FMEA) is used to design improvements. The results of this study indicate the waste of transportation, motion, waiting, over processing, and defects. The proposed improvement is carried out by combining the weighing station and the inspection station, thus providing an estimate of increased efficiency from $39.1 \%$ to $46.69 \%$.
\end{abstract}

Keyword: cement, six sigma, lean manufacturing, value stream mapping, failure mode and effect analysis

\section{Pendahuluan}

PT. Holcim Indonesia Tbk merupakan sebuah perusahaan yang memproduksi semen di Indonesia, dimana salah satu pabriknya ada di Cilacap. Perusahaan mengalami permasalahan, khususnya pada bagian pengemasan (packing) semen. Banyak terjadi pemborosan pada unit ini seperti terdapatnya kegiatan-kegiatan yang tidak bernilai tambah yaitu aktivitas memindahkan kantong semen yang telah ditimbang menuju stasiun pemeriksaan serta tingginya produk cacat sehingga memerlukan rework pada proses pengemasan tersebut. Akibatnya, waktu produksi untuk menghasilkan sejumlah produk menjadi lebih panjang dibandingkan dari waktu yang ditargetkan perusahaan.
Permasalahan yang teridentifikasi di pabrik adalah rendahnya kualitas packing semen, yaitu sesudah bag semen diisi oleh mesin packer hingga ke proses loading (muat). Berdasarkan observasi, ditemukan masalah mengenai produk cacat yang cukup banyak, mencapai $0,16 \%$ sampai $1,03 \%$ yang terjadi sepanjang tahun 2016 hingga 2018. Padahal produk cacat merupakan suatu pemborosan yang akan merugikan perusahaan yang berarti mengurangi keuntungan perusahaan. Dalam dunia industri, pemborosan yang terjadi selama proses produksi termasuk kategori waste.

Dalam bidang manajemen industri, waste didefinikan sebagai kegiatan yang menyerap atau memboroskan sumber daya seperti pengeluaran biaya ataupun waktu tambahan tetapi tidak 
menambahkan nilai apapun dalam kegiatan tersebut. Untuk meminimasi pemborosan atau waste, dapat digunakan pendekatan lean thinking. Lean Thinking atau biasa disebut lean merupakan paradigma holistik yang pada awalnya digunakan Toyota dan difokuskan untuk memberikan nilai (value) kepada pelanggan dengan menghilangkan pemborosan (waste) dari semua aktivitas (Oppenheim, 2009). Gaspersz dan Fontana (2017) menjelaskan bahwa lean merupakan upaya terusmenerus untuk menghilangkan pemborosan (waste) dan meningkatkan nilai tambah (value added) produk yang bertujuan memberikan nilai kepada pelanggan. Tujuan lean adalah meningkatkan terus-menerus customer value melalui peningkatan terus-menerus rasio antara nilai tambah terhadap waste.

Terdapat tujuh jenis pemborosan yang umum dijumpai dalam industri, yaitu (Oppenheim, 2009) :

1. Overproduction : memproduksi lebih daripada kebutuhan pelanggan internal dan eksternal, atau memproduksi lebih cepat atau lebih awal daripada waktu kebutuhan pelanggan internal dan eksternal.

2. Delays (waiting time) : keterlambatan yang tampak melalui orang-orang yang sedang menunggu mesin, peralatan, bahan baku, supplies, perawatan/pemeliharan (maintenance).

3. Transportation : memindahkan material atau orang dalam jarak yang sangat jauh dari satu proses ke proses berikut yang dapat mengakibatkan waktu penanganan material bertambah.

4. Processes : mencakup proses-proses tambahan atau aktivitas kerja yang tidak perlu atau tidak efisien.

5. Inventories : pada dasarnya inventories menyembunyikan masalah dan menimbulkan aktivias penanganan tambahan yang seharusnya tidak diperlukan.

6. Motions : setiap pergerakan dari orang atau mesin yang tidak menambah nilai kepada barang dan jasa yang akan diserahkan kepada pelanggan, tetapi hanya menambah biaya dan waktu saja.

7. Defective products : scrap, rework, customer returns, customer dissatisfaction.

Untuk mengidentifikasi adanya pemborosan, dapat dilakukan dengan membuat value stream mapping (VSM). VSM merupakan suatu alat lean manufacturing yang dapat membantu untuk mengerti aliran material dan informasi dalam suatu proses sekaligus mengetahui aktivitas yang bernilai tambah (value added activity) maupun tidak bernilai tambah (non value added activity) untuk memproses suatu produk dari bahan mentah sampai pengiriman kepada pelanggan. Dengan kata lain, value stream mapping merupakan bagan dari siklus manufaktur sebuah produk yang menunjukkan setiap tahap di dalam proses produksi (Oppenheim, 2009).

Diantara jenis pemborosan dalam sebuah industri adalah keberadaan produk cacat (defective products). Six-sigma merupakan metode pendekatan untuk mengurangi cacat atau variabilitas produk secara dramatik (Gazpersz, 2002). Untuk menjalankan proyek Six Sigma dapat digunakan tahap Define, Measure, Analyze, Improve, Control (DMAIC) (Martim, 2008). Prosedur DMAIC adalah prosedur penyelesaian masalah lima langkah terstruktur yang dapat digunakan untuk menyelesaikan proyek dengan mengimplementasikan solusi yang dirancang untuk menyelesaikan akar permasalahan kualitas dan masalah proses, dan untuk menetapkan praktik terbaik untuk memastikan bahwa solusinya permanen dan dapat direplikasi dalam operasi bisnis lain yang relevan (Montgomery, 2009). Langkah-langkah DMAIC adalah sebagai berikut : a. Define

Pada tahap ini dilakukan identifikasi permasalahan yang terjadi dan akan diselesaikan. Tahap ini juga dilakukan untuk mengidentifikasi aktivitas produksi dan waste serta mengetahui aliran material dan informasi dalam proses pengepakan dengan pembuatan current satete value stream mapping.

b. Measure

Proses mengukur kondisi kinerja perusahaan saat ini dengan melakukan perhitungan nilai DPMO untuk mengetahui tingkat sigma serta process cycle effisiency.

c. Analyze

Pada tahap ini dilakukan analisa penyebab terjadinya produk cacat sehingga dapat mengetahui apa saja masalah yang dihadapi dan bagaimana solusi perbaikan yang akan dibuat dengan menggunakan diagram pareto dan cause and effect diagram.

d. Improve

Pada tahap Improve dibangun rencana tindakan perbaikan dan peningkatan kualitas untuk menghilangkan akar-akar penyebab dan mencegah penyebab-penyebab itu berulang kembali.

e. Control

Langkah terakhir tahapan DMAIC adalah control, tahap ini bertujuan untuk mengevaluasi dan memonitori hasil dari tahap sebelumnya atau hasil implementasi yang telah dilakukan. Tahap ini bertujuan untuk memastikan kondisi yang diperbaiki dapat berjalan dalam waktu yang lama. 
Metode six sigma digunakan untuk menjamin manajemen dapat memperbaiki dan mempertahankan kualitas produk yang dihasilkan, sehingga memenuhi keinginan pelanggan, Penggabungan dari metode lean-six sigma dimaksudkan untuk mengeliminasi pemborosan yang terjadi pada proses manufaktur ataupun jasa, dan untuk meminimalisir produk yang cacat hingga 3.4 cacat per satu juta kesempatan (defects per million opportunities (DPMO)). Beberapa penelitian sebelumnya telah menunjukkan hasil bahwa penerapan lean six-sigma dapat meningkatkan kinerja perusahaan, seperti pada penelitian (Pradana et al., 2018), (Khalil \& Pambudi, 2014), (Hadisupriyanto, 2014), dan (Hill et al., 2018).

Penelitian ini dimaksudkan untuk mengidentifikasi pemborosan dan memberikan rekomendasi untuk menguranginya sekaligus mengurangi produk cacat dengan pendekatan leansix sigma.

\section{Metode Penelitian}

Penelitian ini menggunakan konsep lean six-sigma, dengan mengikuti langkah-langah DMAIC. Hanya saja, tahap control tidak dilakukan karena penelitian hanya sampai memebrikan usulan di perusahaan. Tahap berikut tools yang digunakan adalah :

1. Define

Pada tahap ini akan diidentifikasi masalah dengan menggunakan VSM untuk mengidentifikasi pemborosan.

2. Measure

Dalam tahap measure akan dihitung process cycle effisiencyi (PCE) , DPMO, dan level sixsigma.

3. Analyze

Di tahap ini akan dilakukan analisis terhadap aktivitas yang terjadi sepanjang VSM dan dikaji penyebab produk cacat dengan fish bone diagram.

4. Improve

Tahap improve dilakukan untuk mencari alternative solusi mengurangi pemborosan dan meningkatkan kualitas atau menurunkan produk cacat dengan Failure Mode and Effect Analysis (FMEA).

\section{Hasil dan Pembahasan}

\section{Tahap Define}

Gambar 1 menunjukkan diagram alir proses pengepakan semen di PT X.

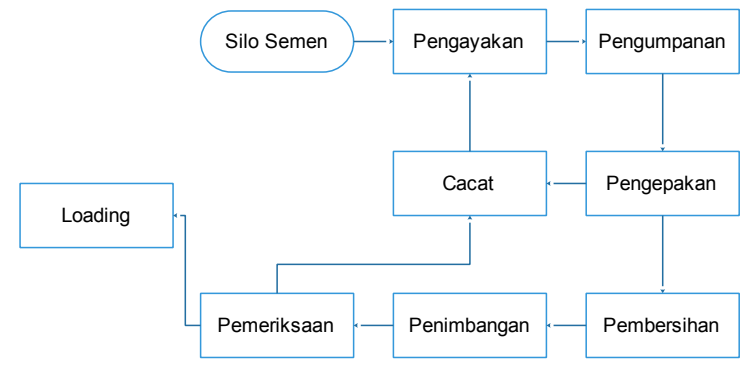

Gambar 1. Diagram Alir Proses Pengepakan Semen

Data cycle-time dan available-time pada proses pengepakan disajikan pada tabel 1 dan tabel 2 .

Tabel 1. Data cycle time tiap proses dalam pengepakan

\begin{tabular}{lcccc}
\hline \multicolumn{1}{c}{ Proses } & $\begin{array}{c}\text { Operator } \\
\text { Cycle } \\
\text { Time }(\mathrm{s})\end{array}$ & $\begin{array}{c}\text { Machine } \\
\text { Cycle } \\
\text { Time }(\mathrm{s})\end{array}$ & $\begin{array}{c}\text { Total } \\
\text { Cycle } \\
\text { Time } \\
\text { (s) }\end{array}$ & $\begin{array}{c}\text { Change } \\
\text { over } \\
\text { time(s) }\end{array}$ \\
\hline $\begin{array}{l}\text { Pengayakan } \\
\begin{array}{l}\text { Pengepakan } \\
\text { Penimbangan }\end{array}\end{array}$ & 0.8 & 1,4 & 1,4 & \\
$\begin{array}{l}\text { Pemeriksaan } \\
\text { Print barcode }\end{array}$ & 1 & 1,8 & 2,6 & 1,2 \\
$\begin{array}{l}\text { Palletizer } \\
\text { Total Cycle }\end{array}$ & $\mathbf{1 , 8}$ & 1,2 & 1,2 & \\
Time & & 0.9 & 1 & \\
\hline
\end{tabular}

Sumber : Pengolahan data primer

Tabel 2. Standard available-time

\begin{tabular}{ccc}
\hline No & Aktifitas & $\begin{array}{c}\text { Available Time } \\
\text { (s) }\end{array}$ \\
\hline $\mathbf{1}$ & Pengayakan & 75.060 \\
$\mathbf{2}$ & Pengepakan & 74.700 \\
$\mathbf{3}$ & Pembersih debu & 75.420 \\
$\mathbf{4}$ & Penimbangan & 75.420 \\
$\mathbf{5}$ & Bag coder & 75.420 \\
\hline
\end{tabular}

Sumber : Pengolahan data primer

Berdasarkan data pada tabel 1 dan 2, kemudian dibuat value sream mapping seperti pada gambar 2 .

\section{Tahap measure}

Pada tahap ini dilakukan perhitungan proses mengukur pada kondisi kinerja yang saat ini dilakukan perusahaan sehingga dapat diketahui pencapaian perusahaan. Untuk itu dilakukan dentifikasi aktifitas value added dan non-value added berdasarkan gambar 2 , yang disajikan pada tabel 3 .

Berdasarkan tabel 3, maka dapat dihitung process cycle effisiensy (PCE) sebagai berikut :

$$
\begin{gathered}
P C E \\
=\frac{\text { valus added time }}{\text { lead time }} \times 100 \% \\
P C E=\frac{470,58}{1203,8} \times 100 \%=39,1 \%
\end{gathered}
$$

Adapun data jumlah produk cacat dan jenisnya, maka dapat dilihat pada tabel 4 . 


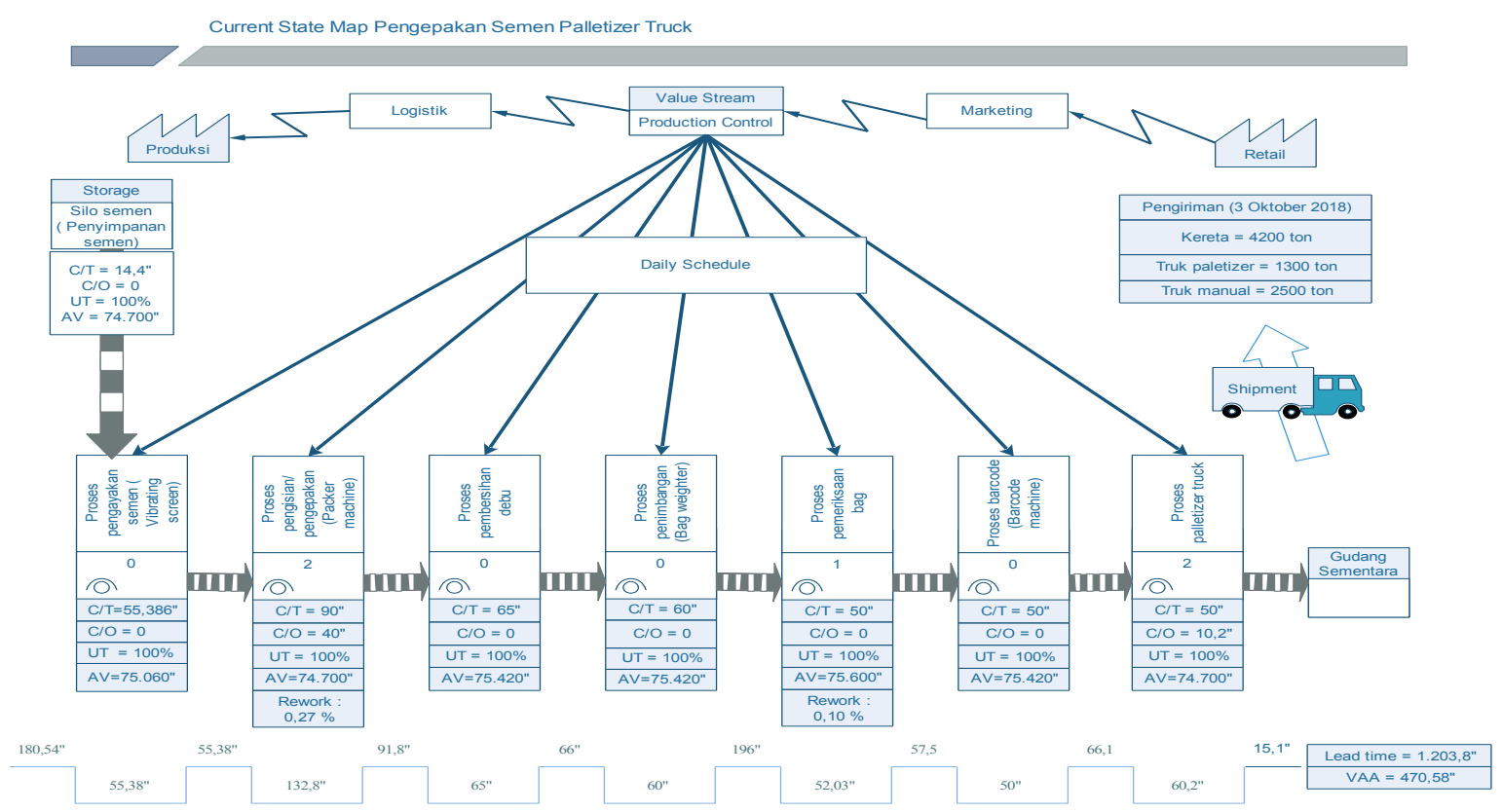

Gambar 2. Current State VSM Proses Pengepakan Semen Palletizer Truck

Tabel 3. Aktivitas value added (VAA) dan non-value added (NVAA)

\begin{tabular}{|c|c|c|c|}
\hline No & Aktivitas & VAA (detik) & NVAA (detik) \\
\hline 1 & Transport semen dari silo melalui air slide ke bin semen & & 14,4 \\
\hline 2 & $\begin{array}{l}\text { Keluarnya semen dari bin semen melalui professional gate ke air } \\
\text { slide }\end{array}$ & & 55,38 \\
\hline 3 & Transport semen melalui air slide ke bucket elevator & & 55,38 \\
\hline 4 & Transport semen dari bucket elevator ke vibrating screen & & 55,38 \\
\hline 5 & Proses pengayakan di mesin vibrating screen & 55,38 & \\
\hline 6 & Pengumpanan semen dengan rotary feeder ke packer machine & & 55,38 \\
\hline 7 & Pemasangan bag ke spout packer & 40 & \\
\hline 8 & Proses pengisian/ pengepakan di packer machine & 90 & \\
\hline 9 & $\begin{array}{l}\text { Mengembalikan produk cacat manufaktur melalui } S C \text { ke bucket } \\
\text { elevator untuk diproses kembali }\end{array}$ & & 1,21 \\
\hline 10 & Rework produk cacat manufaktur & & 1,59 \\
\hline 11 & Transport ke pembersihan debu & & 91,8 \\
\hline 12 & Proses pembersihan debu kantong semen & 65 & \\
\hline 13 & Transport semen ke penimbangan & & 66 \\
\hline 14 & Proses penimbangan & 60 & \\
\hline 15 & Transport bag semen melalui $67 \mathrm{~K}-\mathrm{BC} 1234$ & & 196 \\
\hline 16 & Proses pemeriksaan & 50 & \\
\hline 17 & $\begin{array}{l}\text { Mengembalikan produk cacat operasi melalui } S C \text { ke bucket elevator } \\
\text { untuk diproses kembali }\end{array}$ & & 1,21 \\
\hline 18 & Rework produk cacat operasi & & 0,82 \\
\hline 19 & Transport bag semen 67A-BC1 & & 57,5 \\
\hline 20 & Proses bag coder & 50 & \\
\hline 21 & Transport bag ke palletizer & & 66,1 \\
\hline 22 & Pengambilan/ penggantian pallet & 10,2 & \\
\hline 23 & Proses palett semen & 50 & \\
\hline 24 & Pemindahan 1 batch semen ke gudang sementara & & 15,1 \\
\hline Total & 470,58 detik & 733,22 & \\
\hline $\begin{array}{l}\text { Total } \\
\text { Lead } \\
\text { Time }\end{array}$ & \multicolumn{3}{|l|}{$1.203,8$} \\
\hline
\end{tabular}

Sumber : olahan data primer 
Tabel 4. Data produk cacat bulan November 2016 Oktober 2018

\begin{tabular}{|c|c|c|c|c|c|}
\hline \multirow{2}{*}{$\begin{array}{l}\text { Peri- } \\
\text { ode }\end{array}$} & \multirow{2}{*}{$\begin{array}{c}\text { Jmlh } \\
\text { Produk } \\
\text { (Unit) }\end{array}$} & \multirow{2}{*}{$\begin{array}{l}\text { Jmlh } \\
\text { cacat }\end{array}$} & \multicolumn{3}{|c|}{ Jenis cacat } \\
\hline & & & $\begin{array}{l}\text { Af- } \\
\text { kir }\end{array}$ & $\begin{array}{l}\text { Ope- } \\
\text { rasi }\end{array}$ & $\begin{array}{l}\text { Manu- } \\
\text { faktur }\end{array}$ \\
\hline 1 & 3508745 & 11408 & 296 & 5218 & 5894 \\
\hline 2 & 3817280 & 11136 & 338 & 5034 & 5764 \\
\hline 3 & 3540915 & 10070 & 139 & 4603 & 5328 \\
\hline 4 & 2864250 & 6692 & 163 & 3157 & 3372 \\
\hline 5 & 3354797 & 6118 & 63 & 2624 & 3431 \\
\hline 6 & 3606193 & 5880 & 76 & 2295 & 3509 \\
\hline 7 & 4157050 & 8245 & 100 & 3969 & 4176 \\
\hline 8 & 2829198 & 6722 & 92 & 2825 & 3805 \\
\hline 9 & 4726095 & 9423 & 233 & 4068 & 5122 \\
\hline 10 & 5094525 & 12195 & 203 & 5289 & 6703 \\
\hline 11 & 4660135 & 11100 & 71 & 5241 & 5788 \\
\hline 12 & 4833795 & 19560 & 872 & 10330 & 8358 \\
\hline 13 & 4545598 & 16203 & 0 & 6972 & 9231 \\
\hline 14 & 4409800 & 24011 & 9 & 9064 & 14938 \\
\hline 15 & 4356740 & 40302 & 0 & 5835 & 34467 \\
\hline 16 & 3818418 & 39529 & 62 & 4742 & 34725 \\
\hline 17 & 4008210 & 12655 & 139 & 1706 & 10810 \\
\hline 18 & 4072995 & 13007 & 307 & 1551 & 11149 \\
\hline 19 & 4698170 & 14471 & 93 & 2106 & 12272 \\
\hline 20 & 2747270 & 7882 & 116 & 1019 & 6747 \\
\hline 21 & 5419411 & 20949 & 536 & 2658 & 17755 \\
\hline 22 & 5059015 & 17449 & 343 & 1456 & 15650 \\
\hline 23 & 5425780 & 29578 & 977 & 8657 & 19944 \\
\hline 24 & 5642010 & 37592 & $\begin{array}{c}1.04 \\
5\end{array}$ & 10856 & 25691 \\
\hline 25 & $\begin{array}{c}1011963 \\
95\end{array}$ & $\begin{array}{c}39217 \\
7\end{array}$ & $\begin{array}{c}6.27 \\
3\end{array}$ & $\begin{array}{c}11127 \\
5\end{array}$ & 274629 \\
\hline 26 & 4216516 & 16341 & 261 & 4636 & 11443 \\
\hline $\begin{array}{c}\text { Jumla } \\
\mathrm{h}\end{array}$ & $\begin{array}{c}1011963 \\
95\end{array}$ & $\begin{array}{c}39217 \\
7\end{array}$ & $\begin{array}{c}627 \\
3 \\
\end{array}$ & $\begin{array}{c}11127 \\
5\end{array}$ & 274629 \\
\hline $\begin{array}{c}\text { Rata- } \\
\text { rata }\end{array}$ & 4216516 & 16341 & 261 & 4636 & 11443 \\
\hline
\end{tabular}

Sumber : Olahan data sekunder PT. X

Perhitungan DPMO berdasar tabel 4 :

$$
\begin{aligned}
& D P M O=\frac{\text { Total Defect }}{\text { Total Opportunity }} \times 1.000 .000 \\
& =\frac{392177}{101196395 \times 3} \times 1.000 .000=1291,80
\end{aligned}
$$

Nilai DPMO tersebut dapat dikonversikan ke dalam nilai sigma menjadi 4,51 sigma.

\section{Tahap analize}

Waste yang teridentifikasi selama proses adalah :

$i$. Transportation : terdapatnya aktivitas transport semen dari satu stasiun ke stasiun berikutnya, yaitu dari stasiun penimbangan ke pemeriksaan. Selama proses ini sering terjadi produk cacat, yaitu kemasan ( $b a g$ ) yang pecah.

ii. Motion : mengembalikan semen yang tercecer ketika terjadi bag pecah ke mesin bucket elevator untuk dilakukan pengolahan kembali.

iii. Waiting : bag semen yang telah terisi seringkali menunggu untuk diproses ke stasiun selanjutnya karena terjadi kerusakan suatu part mesin belt conveyor maupun palletizer sehingga produk dapat diproses setelah dilakukan tindakan perbaikan. Waste ini tidak dimasukan ke dalam VSM dikarenakan waste tersebut tidak selalu terjadi.

$i v$. Over processing : rework pada produk defect yang memakan waktu dan tenaga untuk diproses kembali..

v. Defect : banyaknya produk defect seperti cacat afkir, cacat manufaktur, cacat operasi yang terjadi sepanjang alur produksi mengakibatkan kerugian waktu, tenaga, dan biaya.

Berdasarkan tabel 4, maka dapat dibuat diagram pareto untuk melihat jenis cacat terbesar seperti pada gambar 3 .

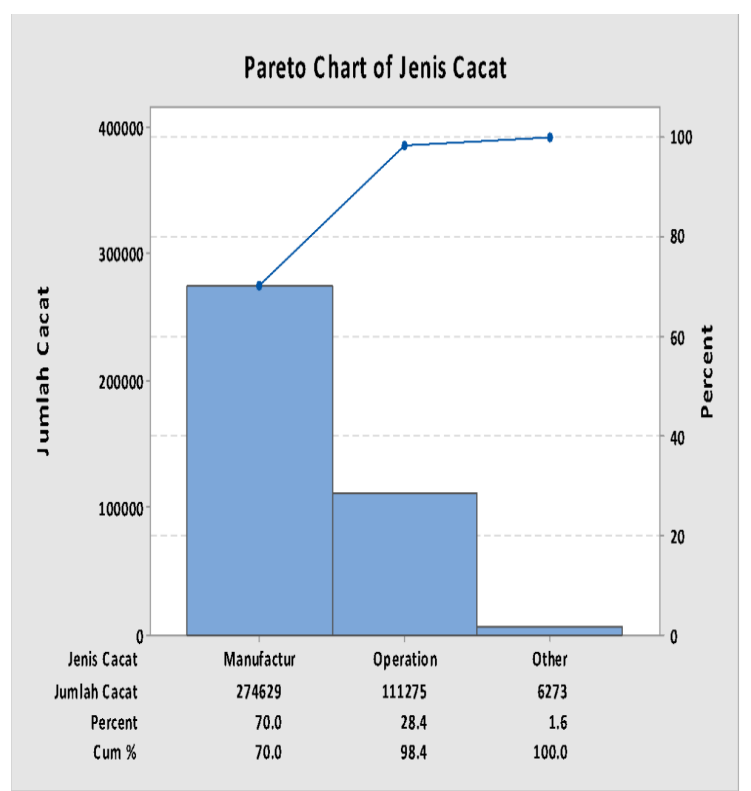

Gambar 3. Pareto jenis cacat pada proses pengepakan

Berikutnya dilakukan analisis terhadap penyebab jenis cacat terbesar, yaitu cacat manufaktur. Diagram fishbone pada gambar 4 menampilkan penyebab cacat manufaktur.

\section{Tahap Improve}

Selanjutnya dibuat Future state value stream mapping (Future VSM). Sebagaimana diketahui, state value stream mapping digunakan untuk mengetahui potensi pengurangan waste. Jika merujuk pada tabel 3, maka terlihat bahwa terdapat 24 aktivitas selama proses pengepakan semen. Setelah dilakukan perbaikan pada proses pengepakan tersebut, maka aktivitas kerja yang baru berjumlah 23 aktivitas produksi yaitu penggabungan stasiun penimbangan dengan stasiun pemeriksaan dengan mengeliminasi aktivitas ke-15 yaitu aktivitas pemindahan bag semen dari stasiun penimbangan ke stasiun pemeriksaan. Keseimbangan lintasan proses pengepakan di perusahaan tetap akan berjalan 
normal dikarenakan aktivitas yang dieliminasi merupakan aktivitas yang

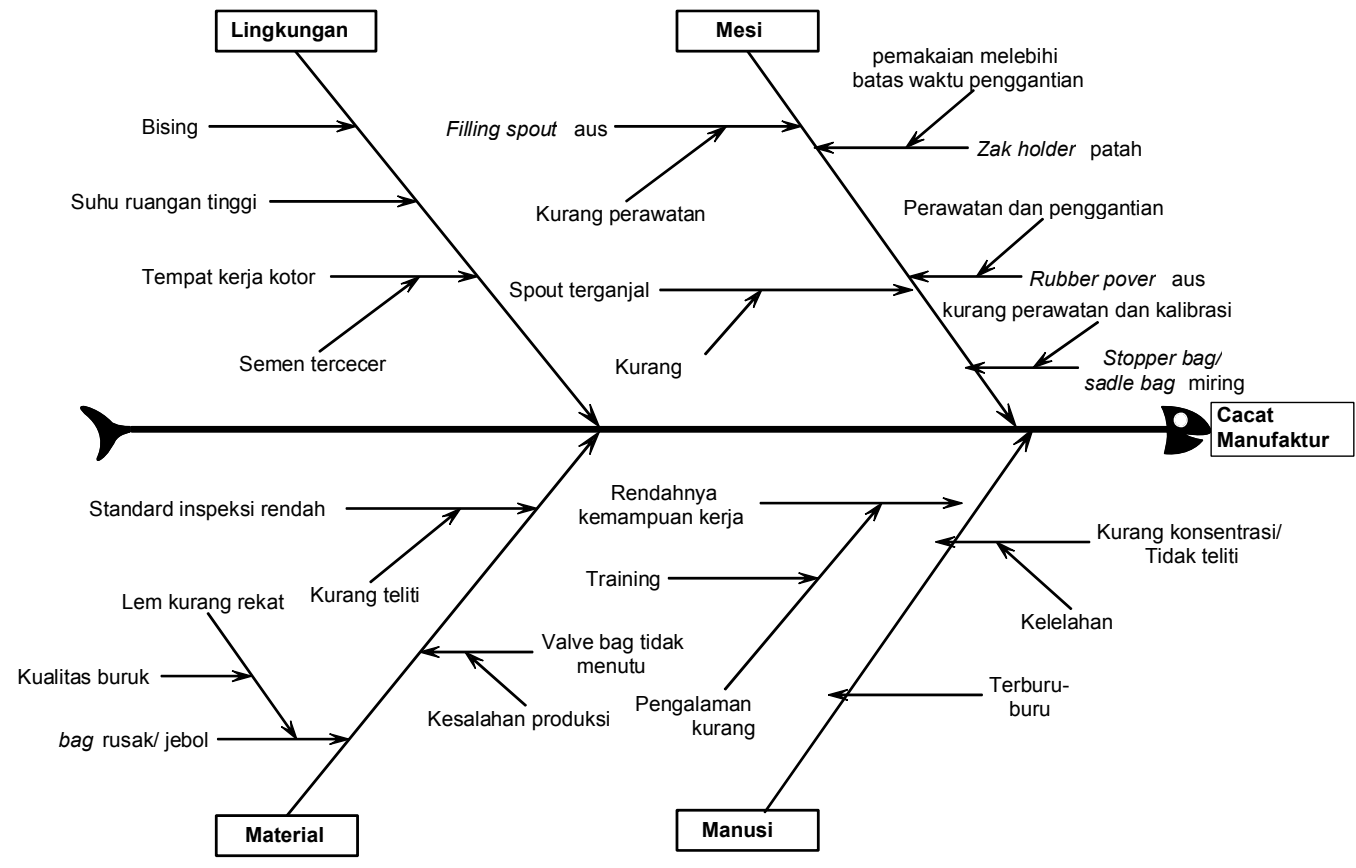

Gambar 4. Fishbone penyebab cacat manufaktur

Tabel 5. Identifikasi aktivitas produksi setelah estimasi

\begin{tabular}{|c|c|c|c|}
\hline No & Aktivitas & VAA & NVAA \\
\hline 1 & Transport semen dari silo melalui air slide ke bin semen & & 14,4 \\
\hline 2 & Keluarnya semen dari bin semen melalui professional gate ke air slide & & 55,38 \\
\hline 3 & Transport semen melalui air slide ke bucket elevator & & 55,38 \\
\hline 4 & Transport semen dari bucket elevator ke vibrating screen & & 55,38 \\
\hline 5 & Proses pengayakan di mesin vibrating screen & 55,38 & \\
\hline 6 & Pengumpanan semen dengan rotary feeder ke packer machine & & 55,38 \\
\hline 7 & Pemasangan bag ke spout packer & 40 & \\
\hline 8 & Proses pengisian/ pengepakan di packer machine & 90 & \\
\hline 9 & $\begin{array}{l}\text { Mengembalikan produk cacat manufaktur melalui } S C \text { ke bucket elevator } \\
\text { untuk diproses kembali }\end{array}$ & & 1,21 \\
\hline 10 & Rework produk cacat manufaktur & & 1,59 \\
\hline 11 & Transport ke pembersihan debu & & 91,8 \\
\hline 12 & Proses pembersihan debu kantong semen & 65 & \\
\hline 13 & Transport semen ke penimbangan & & 66 \\
\hline 14 & Proses penimbangan dan penimbangan & 110 & \\
\hline 15 & $\begin{array}{l}\text { Mengembalikan produk cacat operasi melalui } S C \text { ke bucket elevator untuk } \\
\text { diproses kembali }\end{array}$ & & 1,21 \\
\hline 16 & Rework produk cacat operasi & & 0,82 \\
\hline 17 & Transport bag semen $67 \mathrm{~A}-\mathrm{BC} 1$ & & 57,5 \\
\hline 18 & Proses bag coder & 50 & \\
\hline 19 & Transport bag ke palletizer & & 66,1 \\
\hline 20 & Pengambilan/penggantian pallet & 10,2 & \\
\hline 21 & Proses palett semen & 50 & \\
\hline 22 & Pemindahan batch semen ke gudang sementara & & 15,1 \\
\hline Total & $\begin{aligned} 470,58 \\
\end{aligned}$ & $\mathbf{5 3 7 , 2 2}$ & \\
\hline $\begin{array}{l}\text { Total } \\
\text { Lead } \\
\text { Time }\end{array}$ & $\mathbf{1 . 0 0 7 , 8}$ & & \\
\hline
\end{tabular}


ditampilkan pada gambar 5. Berdasarkan tabel 5, diketahui nilai value added dan non-value added berturut-turut setelah estimasi adalah 470,58 detik dan 537,22 detik. Maka nilai process cycle efficiency setelah estimasi adalah 46,69\%.

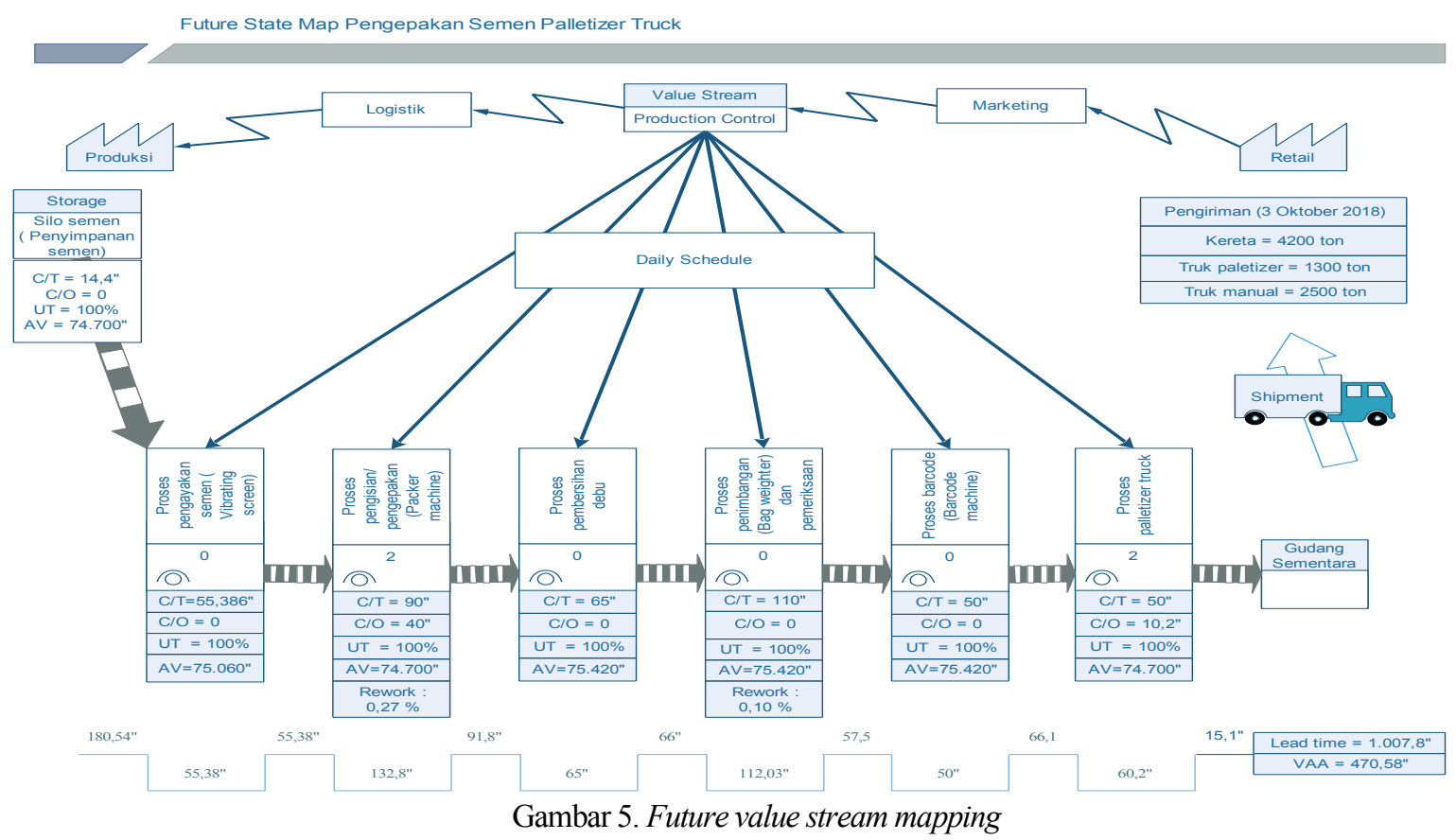

Tahap improve juga dilakukan dengan membuat FMEA seperti disajikan dalam tabel 6 . FMEA berfungsi untuk memberikan nilai pada setiap klasifikasi dari nilai severity, occurance dan detection berdasarkan potensi dari efek kegagalan, penyebab dan proses control saat ini untuk menghasilkan nilai Risk Priority Number (RPN). Dalam tabel 6 sekaligus juga dicantumkan usulan perbaikan yang dapatb dilakukan perusahaan.

Setelah diketahui nilai-nilai Risk Priority Number $(R P N)$ terhadap kegagaan-kegagalan yang pada proses pengepakan semen di department packhouse PT. X, maka disusun suatu usulan tindakan perbaikan yang dapat dilakukan untuk meningkatkan kualitas produksi dan menekan terjadinya defect. Usulan yang dapat diberikan dibuat dengan memperhatikan fishbone yang menggambarkan penyebab cacat manufaktur (gambar 4). Adapun usulan perbaikan adalah sebagai berikut:

a. Dari segi mesin

Keadaan komponen mesin yang sudah aus/ rusak seperti zak holder, stopper bag, rubber pover, filling spout, terganjalnya spout dan kurang kalibrasi serta umur mesin semakin tua yang sering kali menjadi penyebab cacatnya produk. Untuk itu perlu dilakukan perawatan dan pemeliharaan mesin packer melalui proses kalibrasi secara berkala, menetapkan planned maintenance serta penggantian komponen- komponen mesin yang seringkali menyebabkan defect pada proses packing semen.

b. Dari segi material

Kualitas bag semen yang baik dihasilkan dari bahan baku bag yang baik pula. Adanya material yang menyebabkan cacat manufaktur adalah dari faktor lem perekat pada pembuatan bag semen yang kurang kuat sehingga bag semen mudah jebol pada saat diisi. Selain itu juga ditemukan bag yang cacat lolos dari inspeksi sehingga terbawa ke mesin pengepakan. Maka dari itu perlu dilakukan pengawasan dan inspeksi lebih ketat terhadap bag semen yang akan masuk ke bagian pengepakan dan memakai lem kualitas terbaik dengan menguji terlebih dahulu kekuatan dan ketahanan lem yang akan dipakai.

c. Dari segi lingkungan

Lingkungan di bagian pengepakan tidak nyaman bagi pekerja, diantaranya karena debu dan bising akibat mesin. Lingkungan yang tidak nyaman pun juga memberikan dampak terhadap semangat pekerja. Di sini perlu penyediaan Alat Pelindung Diri (APD) berupa sarung tangan, tutup telinga, kaca mata, masker, helm, serta dilakukan penggalakkan penggunaannya. (helm), pengawasan lebih ketat penggunaan APD kepada setiap pekerja di lapangan. Di area kerja juga didapati 
penerangan yang kurang, sehingga perlu penambahan lampu.

d. Dari segi manusia

Manusia merupakan salah satu penyebab terjadinya kerusakan pada pengepakan disebabkan oleh beberapa hal yaitu kurang konsentrasi, sehingga mengakibatkan kesalahan saat proses pemasukan bag semen ke spout mesin packer. Disamping itu, teridentifikasi rendahnya kemampuan pekerja yang terlihat dari kurangnya pengetahuan dan ketrampilan dalam mengoperasikan mesin. Maka dari itu perlu dilakukan pelatihan, pengawasan, dan pemberian motivasi kerja terhadap operator-operator baru maupun lama sehingga lebih mengetahui penanganan proses produksi untuk mengurangi kesalahan yang disebabkan oleh human error.

Tabel 6. Failure mode and effect analyze

\begin{tabular}{|c|c|c|c|c|c|c|c|c|}
\hline $\begin{array}{l}\text { Modus } \\
\text { of } \\
\text { failure }\end{array}$ & $\begin{array}{l}\text { Cause of } \\
\text { failure }\end{array}$ & $\begin{array}{l}\text { Effect } \quad \text { of } \\
\text { failure }\end{array}$ & $\begin{array}{l}\text { Degree } \\
\text { of } \\
\text { severity }\end{array}$ & $\begin{array}{l}\text { Frequency } \\
\text { of } \\
\text { occurance }\end{array}$ & $\begin{array}{l}\text { Chance } \\
\text { of } \\
\text { detection }\end{array}$ & $R P N$ & Rank & Saran perbaikan \\
\hline \multirow[t]{12}{*}{$\begin{array}{l}\text { Cacat } \\
\text { manu- } \\
\text { faktur }\end{array}$} & $\begin{array}{l}\text { Zak holder } \\
\text { patah }\end{array}$ & $\begin{array}{lr}\text { Bag semen } \\
\text { jatuh saat disi } \\
\text { dalam mesin } \\
\text { packer }\end{array}$ & 6 & (1) & 5 & 150 & 2 & \multirow{5}{*}{$\begin{array}{l}\text { Meningkatkan } \\
\text { perawatan pada } \\
\text { mesin packer } \\
\text { dengan cara } \\
\text { melakukan } \\
\text { kalibrasi secara } \\
\text { berkala dan } \\
\text { penjadwalan } \\
\text { penggantian } \\
\text { part mesin } \\
\text { sebelum part } \\
\text { tersebut dapat } \\
\text { menimbulkan } \\
\text { kerusakan pada } \\
\text { bag saat } \\
\text { dilakukan } \\
\text { pengepakan. }\end{array}$} \\
\hline & $\begin{array}{l}\text { Rubber } \\
\text { pover aus }\end{array}$ & $\begin{array}{ll}\text { Bag } & \text { semen } \\
\text { robek }\end{array}$ & 5 & 5 & 5 & 125 & 3 & \\
\hline & $\begin{array}{l}\text { Stopper bag/ } \\
\text { sadle bag } \\
\text { miring }\end{array}$ & $\begin{array}{l}\text { Penjatuhan } \\
\text { melintang dan } \\
\text { menyebabkan } \\
\text { pecah }\end{array}$ & 7 & 5 & 6 & 210 & 1 & \\
\hline & $\begin{array}{l}\text { Filling spout } \\
\text { aus }\end{array}$ & $\begin{array}{ll}\begin{array}{l}\text { Bag } \\
\text { robek }\end{array} & \text { semen } \\
\end{array}$ & 5 & 5 & 5 & 125 & 4 & \\
\hline & $\begin{array}{l}\text { Spout } \\
\text { terganjal }\end{array}$ & $\begin{array}{l}\text { Pengepakan } \\
\text { terganggu }\end{array}$ & 4 & 5 & 5 & 100 & 5 & \\
\hline & $\begin{array}{l}\text { Kemampuan } \\
\text { kerja kurang }\end{array}$ & $\begin{array}{l}\text { Pengerjaan } \\
\text { menjadi lebih } \\
\text { lama }\end{array}$ & 3 & 5 & 2 & 30 & 11 & $\begin{array}{l}\text { Pelatihan lebih } \\
\text { matang pada } \\
\text { setiap operator }\end{array}$ \\
\hline & $\begin{array}{l}\text { Kurang } \\
\text { konsentrasi/ } \\
\text { tidak teliti }\end{array}$ & $\begin{array}{l}\text { Pemasukan } \\
\text { kantong ke } \\
\text { spout salah } \\
\text { dan menjadi } \\
\text { lebih lama }\end{array}$ & 3 & 5 & 2 & 30 & 13 & \begin{tabular}{lr}
\multicolumn{2}{l}{ Pemberian } \\
motivasi & kerja \\
dan & arahan \\
pada & setiap \\
pekerja &
\end{tabular} \\
\hline & $\begin{array}{l}\text { Operator } \\
\text { Terburu- } \\
\text { buru }\end{array}$ & $\begin{array}{l}\text { Pemasukan } \\
\text { kantong tidak } \\
\text { tepat, mudah } \\
\text { terjatuh }\end{array}$ & 3 & 5 & 2 & 30 & 12 & \begin{tabular}{lr}
\multicolumn{2}{l}{ Pemberian } \\
motivasi & kerja \\
dan & arahan \\
pada & setiap \\
pekerja &
\end{tabular} \\
\hline & Bising & $\begin{array}{l}\text { Konsentrasi } \\
\text { kerja } \\
\text { terganggu }\end{array}$ & 3 & 5 & 3 & 45 & 9 & $\begin{array}{l}\text { Monitor } \\
\text { lapangan pada } \\
\text { pekerja }\end{array}$ \\
\hline & $\begin{array}{l}\text { Suhu } \\
\text { ruangan } \\
\text { tinggi }\end{array}$ & $\begin{array}{l}\text { Konsentrasi } \\
\text { pekerja } \\
\text { terganggu }\end{array}$ & 3 & 5 & 3 & 45 & 10 & $\begin{array}{l}\text { Penambahan } \\
\text { sirkulasi udara } \\
\text { dan monitor APD } \\
\text { pekerja } \\
\text { dilapangan }\end{array}$ \\
\hline & $\begin{array}{l}\text { Tempat } \\
\text { kerja kotor } \\
\text { dan berdebu }\end{array}$ & $\begin{array}{l}\text { Konsentrasi } \\
\text { pekerja } \\
\text { terganggu }\end{array}$ & 3 & 5 & 3 & 45 & 8 & $\begin{array}{lr}\text { Monitor } & \text { APD } \\
\text { pekerja } & \text { di } \\
\text { lapangan } & \\
\end{array}$ \\
\hline & $\begin{array}{l}\text { Valve bag } \\
\text { tidak } \\
\text { menutup }\end{array}$ & Bag bocor & 4 & 5 & 3 & 60 & 7 & $\begin{array}{l}\text { Monitor } \\
\text { pembuatan bag } \\
\text { semen }\end{array}$ \\
\hline
\end{tabular}




\begin{tabular}{|l|l|l|l|l|l|l|l|l|}
\hline & $\begin{array}{l}\text { Bag rusak/ } \\
\text { jebol }\end{array}$ & $\begin{array}{l}\text { Pengepakan } \\
\text { terganggu }\end{array}$ & 4 & 5 & 3 & 60 & 6 & $\begin{array}{l}\text { Monitor } \\
\text { pembuatan dan } \\
\text { inspeksi } \\
\text { ketat }\end{array}$ \\
\hline
\end{tabular}

Berdasarkan pengolahan dan analisis data dengan menggunakan metode lean six sigma pada tahap sebelumnya diperoleh usulan yaitu menggabungkan stasiun penimbangan dan stasiun pemeriksaan dengan mengeliminasi aktivitas yang tidak memberikan nilai tambah pada produk yaitu aktivitas transport bag semen dari stasiun penimbangan menuju stasiun pemeriksaan serta melakukan peningkatan perawatan dan pemeliharaan pada mesin packer dengan cara melakukan kalibrasi secara berkala, menetapkan planned maintenance dan penggantian terhadap kerusakan komponen-komponen mesin packer sesuai batas pemakaian yang seringkali kerusakan tersebut menyebabkan defect pada proses packing semen sehingga perbaikan tersebut dapat meningkatkan kecepatan dalam pengepakan semen atau produk sampai ke pelanggan dengan tepat waktu dan menghasilkan kualitas produk yang lebih baik serta kepuasan pelanggan dapat terpenuhi.

\section{Kesimpulan}

Dari hasil analisis dan pembahasan terhadap hasil pengamatan maka dapat diambil kesimpulan sebagai berikut :

1. Berdasarkan hasil penelitian dan analisa data di unit pengepakan semen PT. Holcim Indonesia Tbk, pabrik Cilacap sesuai metode Lean six sigma dapat diketahui bahwa PCE sebesar $39,1 \%$ dan level sigma 4,51 .

2. Faktor - faktor penyebab terjadinya produk cacat berdasarkan Cause and effect diagram antara lain dari segi manusia (kurangnya ketelitian dan pengalaman kerja dari operatoroperator), mesin (kondisi mesin yang kurang optimal, kurangnya perawatan terhadap mesin produksi), lingkungan (sangat berdebu, tempat produksi kurang penerangan, dan suara yang mengganggu/ bising) dan material ( kualitas lem kurang baik, pengeleman yang tidak rata sehingga sambungan lapisan antar bag tidak merekat dengan kuat ).

3. Alternatif perbaikan pada aktivitas pengepakan semen melalui future state valu stream mapping menghasilkan estimasi PCE sebesar $46,69 \%$, dimana diusulkan penggabungkan stasiun penimbangan dan stasiun pemeriksaan dengan mengeliminasi aktivitas yang tidak memberikan nilai tambah yaitu aktivitas transport bag semen dari stasiun penimbangan ke stasiun pemeriksaan. Sedangkan berdasar FMEA, untuk mengurangi produk cacat, maka diusulkan peningkatan terhadap perawatan dan pemeliharaan pada mesin packer dengan cara melakukan kalibrasi secara berkala, menetapkan planned maintenance dan penggantian terhadap kerusakan komponenkomponen mesin packer sesuai batas pemakaian yang seringkali menyebabkan defect pada proses packing semen.

\section{Daftar Pustaka}

Gaspersz, Vincent, Balanced Scorecard dengan Six Sigma, Gramedia, Jakarta, 2002.

Gaspersz dan Fontana, (2017). "Lean Six Sigma for Manufacturing and Service Industries". Bogor : Vinchristo Publication.

Hadisupriyanto, H, (2014). Penerapan Lean Six Sigma Concept Untuk Perbaikan Lini Produksi, Prosiding Seminar Nasional IENACO - 2014, 120-126, 2014,

Hill, J., Thomas, A. J., Mason-Jones, R. K., \& ElKateb, S., (2018). The implementation of a Lean Six Sigma framework to enhance operational performance in an MRO facility. Production and Manufacturing Research, Vol. 6, No. 1, pp 26-48.

Khalil, M., \& Pambudi, T.,( 2014). Implementasi Lean Six Sigma dalam Peningkatan Kualitas Dengan Mengurangi Produk Cacat NG DROP di mesin Final Test Produk HL 4.8 di PT. SSI, Jurnal PASTI, Vol. VIII, No.1, pp 14-29.

Martim, J. W. Operational Excelence Using Lean Six Sixma to Translate Customer Value through Global Supply Chains, Auerbach Publications Taylor and Francis Group, New York, 2008.

Montgomery, D. C. (2009). Introduction To Statistical Quality Control (sixth edition), John Wiley \& Son, 2009.

Oppenheim, B. W.,(2011). Lean for Systems Engineering with Lean Enablers for Systems Engineering. In Lean for Systems Engineering with Lean Enablers for Systems Engineering.

Pradana, A. P., Chaeron, M., \& Khanan, M. S. A., (2018). Implementasi Konsep Lean Manufacturing Guna Mengurangi Pemborosan Di Lantai Produksi. Opsi, Vol. 11, No. 1, pp. 14. 